\title{
An approach to the cooperation for innovation in the service sector
}

\begin{abstract}
This study examines how firms cooperate for innovation in the services sector. We tested the theoretical development using cluster analysis and ordinal logit regression analysis with firm-level data collected from the Spanish Technological Innovation Panel (PITEC) for the period 2011-2013. Overall, 2,622 service firms have been used. This research contributes as follows: firstly, the findings show that the greater degree of penetration into the innovation modes of the firms means that the intensity of the use of cooperative agreements as well as the diversity of cooperative partners increases. Secondly, the empirical evidence for the taxonomy of innovation development in the service sector provides firms with the ways how to innovate based on their strategic orientation.
\end{abstract}

Keywords: Service Sector; Innovation; Cooperation; Strategic Orientation.

\section{Introduction}

The cooperation agreement and its effects on innovation output have been extensively researched, especially in the manufacturing sector (Miotti and Sachwald, 2003; van Beers and Zand, 2014; Guisado-González et al., 2016; Arranz et al., 2019a), and this interest is growing in the service sector (Tether, 2002; Tether and Tajar, 2008; McCole et al., 2008; Aas and Pedersen, 2010; Hertog et al., 2011; Trigo and Vence, 2012; Gallouj et al., 2013; Osborne and Strokosch, 2013; Jevnaker et al., 2015; Chowdhury et al., 2016; Fu et al., 2017; Nardelli, 2017; Li et al., 2019). Yet, Koschatzky (1999) points out that the innovation activity of a firm reflects its ability to interact with other partners. Prior studies have identified that it is common in service firms to establish agreements with consumers to acquire knowledge of customer needs and preferences and mitigate the risks and uncertainties of the market (Trigo and Vence, 2012; Frow et al., 2015; Chowdhury et al., 2016). Moreover, Tether (2002) indicates that service firms cooperate with their competitors to collaborate and solve common problems, such as the generation of economies of scale needed in the innovative process, or to solve industry regulatory constraints. Freel (2006) and Chowdhury et al. (2016) point out that the key to co-creation in the service sector is collaboration, where the various actors are involved through a process of resource integration. Thus, the activities of the service are 
characterized by interaction, collaboration and communication with clients, suppliers and other stakeholders, which creates the framework to intensify the probability of establishing cooperation agreements (Sundbo and Gallouj, 2000; Tether and Tajar, 2008; Oliveira and von Hippel, 2011; Li et al., 2019).

However, despite the importance of cooperation for innovation in the services sector (Yang, 2016; Tether, 2002), the literature shows scattered and inconclusive results (Trigo and Vence, 2012; Gallouj et al. 2013; Mina et al., 2014; Freel, 2016). This is due to various reasons as follows: On the one hand, there is the classic argument that the service industry has received relatively little attention from innovation scholars in comparison to the manufacturing sector (Gallouj and Savona, 2009; Trigo and Vence, 2012). In addition to this, there is the view that the analysis has been developed from different approaches, producing diverse results making it difficult to compare and generalize (Miozzo and Soete, 2001; Tether, 2002; Tether, 2005; Chang et al., 2012). On the other hand, the heterogeneity of the activities comprising the service sector makes it difficult to undertake the search for innovation and cooperation patterns in this sector (Evangelista, 2000; Hollenstein, 2003; Freel, 2006; Castellacci, 2010; Chang et al., 2012). It can be found companies with important differences in terms of the scientific and technological base, capital intensity, and size (Evangelista, 2000; Evangelista and Savona, 2003). The investigation has not been alien to the plurality of innovation and cooperation patterns within the service industry, generating a profusion of studies that try to classify the typology of service innovation (Ffor example, see Soete and Miozzo, 1989; Gallouj and Weinstein, 1997; Evangelista, 2000; Miozzo and Soete, 2001; Sundbo and Gallouj, 2000; Hollenstein, 2003; Hipp and Grupp, 2005; De Jong and Marsili, 2006; Tether and Tajar, 2008; Vargo and Lusch, 2008; Pyka et al., 2009; Trigo and Vence, 2012; Mina et al., 2014; Kim et al., 2015; Helkkula et al., 2018). However, despite these important contributions, the categorization is far from conclusive, as shown by the diversity of results obtained ${ }^{1}$, regardless of their being derived from the multiplicity of the variables which form the classification pattern, or from other approaches of studies

\footnotetext{
${ }^{1}$ For example, one group of studies have researched cooperation in the service sector as a variable with which to create taxonomy (for example, see Trigo and Vence, 2012), but has failed to analyse the effect of cooperation on innovation output. Whereas other studies have focused on cooperation, establishing behaviour patterns, but while still follow the traditional classification of economic ranking of the service sector without considering the heterogeneity regarding innovation patterns (Kaiser, 2002; Un and Montoro, 2009; Un et al., 2010).
} 
considered (Hollestein, 2003; Tether and Tajar, 2008). Kim et al. (2015) and Trigo and Vence (2012) conclude that there is a real need for research to shed additional light on the linkages between cooperation and innovation in the service sector.

Our study explores how companies cooperate in innovation in the services sector. We assume the non-homogeneity of the service sector in terms of its innovative behaviour (Gallouj and Weinstein, 1997; Gallouj et al., 2013.). Thus, prior research emphasized that regardless of industry affiliation is critical to find the groups of firms characterized by similar patterns of innovation (Gallouj and Weinstein, 1997; Hollenstein, 2003; Tether and Tajar, 2008; Peneder, 2010; Trigo and Vence, 2012). According to Pavitt (1984) and Gallouj and Weinstein (1997), to classify companies in terms of their innovation and cooperation behaviours in the service sector is needed to find groups of companies which are characterized by similar patterns of innovation, that are conceptualized as non-ordered categories of innovation modes, innovation forms or innovation strategies (Gallouj and Weinstein, 1997). In contrast to studies which viewed the innovation strategy of the firm in the service sector as determined by economic and structural variables (Evangelista, 2000; Chang et al., 2012), we argue that the innovation modes or innovation strategies are based on the strategic orientation of firms (Narver and Slater 1990; Brickson, 2005; Camarero and Garrido, 2012; Mallin, et al., 2013). From the Resource-Based View, an important firm capability is its strategic orientation (Mallin, et al., 2013). Strategic orientation reflects the firm's philosophy of how to conduct business through a deeply rooted set of values and beliefs that guides the firm's attempt to achieve superior performance (Gatignon and Xuereb, 1997). Olavarrieta and Friedman (2008) suggest that innovativeness associates with a proactive strategic orientation, which consists of a firm being aggressive, competitive, and risk-taker. Thus, using the Resources Based View as theoretical approach, we hypothesize that the greater the development of innovative resources in the firm, as a consequence of a proactive strategic orientation to the innovation, the greater will be its tendency to cooperate; and on the contrary, companies with a reactive strategic orientation to the innovation (which has not internalized the innovation process and therefore, these resources and capabilities), will be less likely to cooperate.

We empirically test these questions for the case of Spain. Companies in the service sector in Spain make up over $75 \%$ of the GDP, and $76.2 \%$ of employment is generated in this sector 
(INE, 2020). Therefore, the growing role of services makes that studying these companies and how they develop cooperation projects to innovate is highly relevant to the Spanish economy. Moreover, in terms of cooperation and innovation, the choice of Spain is interesting because the relative weight of this sector is quite similar to the average that is registered in the countries of the European Union. This allows us to obtain an adequate perspective of cooperative behaviour for innovation in the service sector companies. In our study, we used data from the Spanish Technological Innovation Panel (Panel de Innovation Technological, PITEC; FECYT, 2014) which is a statistical instrument for studying the innovation activities of Spanish companies over time. The dataset is based on the Community Innovation Survey (CIS) framework, which has proved to be a valid and reliable tool to understand innovation dynamics, enabling direct comparisons with results of previous literature on similar studies (e.g. Ballot et al, 2015; Evangelista and Vezzani, 2010). In this study, the focus is on service firms across 15 industries, based on the Spanish National Classification of Economic Activity (NACE-2009) over the period 2011-2013. Our final sample contained 2622 service firms.

\section{Literature Review}

\section{Innovation and service sector}

Services include a vast array of different and often very complex activities, making them difficult to define (Spohrer and Maglio, 2008). The literature describes several definitions of the services sector, emphasizing different aspects or characteristics. Gronroos (1990) highlighted in the definition of services, the development of activity or series of activities provided as a solution to customer problems. The characteristics of the service are defined that it is the development of an economic activity whose output is not a physical product (Baruch et al. 1987), or it is intangible and perishable (Sasser et al., 1978). Den Hertog (2000), and Spohrer and Maglio (2008) emphasized co-creation as the main characteristic and pointed out that it is the development of a series of activities, where clients and suppliers working together to transform some client-controlled state. In our paper following Fitzsimmons et al. (2008) which integrates previous definitions, we conceptualize services as a time-perishable, intangible experience performed for a customer acting in the role of coproducer. Based on this definition of services, intangibility and inseparability (interactivity 
of production and consumption) are considered as the key characteristics of services. In fact, as a result of these characteristics, service processes require the participation of the client (Tether and Tajar, 2008; Fuglsang and Rønning, 2015; Hsieh and Hsieh, 2015; Chowdhury et al., 2016; Torugsa et al., 2018), which results in cooperation with external actors in the value chain.

Innovation in services is considered as a multi-dimensional phenomenon because it can occur in a variety of forms in the value creation process of a service-dominant firm (Sastre, 2015; Chowdhury et al., 2016). Tether (2005) already pointed out that companies innovate in the service sector differently than in the manufacturing sector. Firstly, these authors emphasize that innovation in services brings to the fore softer aspects of innovation based on skills and inter-organizational cooperation practices. Den Hertog (2000) points out that service innovation often coincides with new patterns of product distribution, client interaction, and quality control and assurance. This first particularity of service innovation (Miles, 1993) supposes that the role of technological innovation is moderated, emphasizing the importance of non-technological elements such as organizational and marketing innovations in the service innovation (Freel, 2006; Jääskeläinen et al., 2013). Therefore, according to Den Hertog (2010, p.19), service innovation is a new service experience or service solution in one or several of the following dimensions: new service concept, new customer interaction, new value system/business partners, new revenue model, new organization or technological service delivery system. Secondly, the service innovation literature views co-creation as a second particularity, in which multiple actors participate and involve complex interactions in business networks (Koschatzky, 1999; Chesbrough, 2011; Hidalgo and D'Alvano, 2014; Mina et al., 2014; Chowdhury et al., 2016). While Payne et al. (2008) emphasize the benefit of co-creation, Ballantyne and Varey (2006) point out that cocreation involves spontaneous, collaborative, and dialogical interactions between parties. In fact, Hsieh and Hsieh (2015, p. 2268) highlight that co-creation affects customer relationship strength (relational resource), valuation of knowledge (informational resource), and capability of customization (organizational resource), facilitating service innovation. Therefore, and in line with Evangelista and Sirilli (1998), four main features are specific to innovation in services in comparison with the manufacturing sector. These are the close interaction between production and consumption; the increasing information content of 
services; the large and growing role played by human resources in service production, and the great importance of organizational change as a means of producing and delivering services.

\section{The cooperation for innovation in the service sector}

To analyze the role of development cooperation in the service sector, the theoretical framework used in this paper is the Resource-Based View (RBV) of the firm (Barney, 1991; Peteraf, 1993). RBV states that the development of valuable resources is the source of a firm's competitive advantages (Eisenhardt and Martin, 2000; Lawson and Samson, 2001). RBV scholars understand firms as groupings of resources which are, in turn, linked to their superior performance (Barney, 1991; Peteraf, 1993). In this sense, as Eisenhardt and Schoonhoven (1996) have pointed out, cooperation agreements are a way for most companies to obtain critical resources. In sum, a key aspect from the resource-based perspective is that competitive advantage arises not only from proprietary resources but also from the possibility of accessing these resources through partnerships or cooperation. To search for assets, firms may turn to different types of partners, such as consumers, suppliers, competitors, universities, among others (Hagedoorn et al., 2006; Schneider and Spieth, 2013; Badillo and Moreno, 2016; Hyll and Pippel, 2016; Arranz et al., 2019b).

Specifically, cooperation for innovation has been extensively discussed in the literature of innovation. Thus, Tether (2002) defined cooperation for innovation as the active participation in joint $R \& D$ projects and other innovation activities with other organizations. Hagedoorn et al. (2006) pointed out that the objectives of the cooperation for innovation include both economic benefits as cost reduction, risk sharing, access to financial capital, complementary assets, improved capacity for rapid learning, and knowledge transfer, as well as technological benefits. Firms that use cooperation emphasize the difficulties involved for the company in internalizing technological activities due to size (the need to generate scale economies) or to the uncertainty of technological processes in terms of results and time (Arranz et al., 2019b).

As we have pointed out previously, a particularity of service innovation is co-creation, in which through the integration and collaboration with both clients, suppliers, and other organizations, the innovative process is developed (Chowdhury et al., 2016; Freel, 2016; Kim et al., 2015; Hsieh and Hsieh, 2015; Gallouj et al., 2013; Pyka et al., 2009), expecting cooperation agreements for innovation to be usual practice in the service sector. However, 
Chowdhury et al. (2016) highlight the complexity of co-creation, emphasizing a series of difficulties such as role conflicts and ambiguity, or opportunism behaviour and power plays. Moreover, Arranz et al. (2016) point out that despite the advantages of cooperation for the innovative process, cooperation entails a controversial role, as a consequence of the resource and skills needed to implement a cooperation agreement. Thus, negotiations on the agreement and the subsequent management are activities that require the company's possession of specific resources and skills, intending to develop tasks such as coordination between two or more partners, solve problems arising from conflict, the lack of trust and understanding, and cultural differences. Therefore, we consider that the decision to cooperate in the development of innovation is a balance between the own resources and skills and the requirements of these agreements.

\section{The strategic orientation in the service companies}

From RBV, firm resources can be classified as assets and capabilities (Day, 1994; Hunt and Morgan, 1995). Assets are the more tangible resources, while capabilities differ from assets in that they are difficult to quantify monetarily and they encompass skills that are embedded deeply in organizational routines and practices (Barney, 1991; Day, 1994). Following Zhou et al. (2005), an important firm capability is its strategic orientation. Narver and Slater (1990) consider that firm's strategic orientation reflects the strategic directions implemented by a firm to create the proper behaviours for the continuous superior performance of the business. Several types of strategic orientations in the firm are indicated in the literature such for example, market, technological or entrepreneurial orientation, without these being exclusive. Zhou et al. (2005) consider that technological orientation focuses predominantly on new technologies, while market orientation emphasizes the need for the entire organization to acquire, disseminate, and respond to market from the firm's target buyers and current and potential competitors; in the case of entrepreneurial orientation, they assume the firm's propensity to engage in the pursuit of new market opportunities, meaning a highly proactive toward market opportunities and tolerance of risk. From an operational point of view, firm's strategic decisions suppose that companies emphasize developing resources and capabilities in tandem with their orientations (Zhou et al., 2005; Ferrell et al., 2010; Jiménez - Zarco et al., 2011; Camarero and Garrido 2012; Mallin et al., 2013). For example, Camarero and Garrido (2012) point out that many museums are 
developing a market orientation as a strategic philosophy. This orientation involves the development of processes and organizational routines, where a service orientation focused on quality and custody must be coordinated to fulfil the museum's mission.

In line with our research question that focuses on the role of cooperation for innovation in the service sector, we will base on the strategic orientation towards innovation. Thus, a firm with an innovation orientation (proactive orientation) will prioritize its strategic decisions to develop innovation capabilities and resources. Hurley and Hult (1998) considered the innovation capability as a result of the innovation process, that is, as the ability of the organization to adopt and implement new ideas, processes, or products successfully. Moreover, it has been emphasized that acquire innovation capabilities, not only derive for possession of competences but also the previous development of innovations (Arranz et al., 2019a; Tether, 2005). We assume that companies with a reactive orientation to innovation will focus their efforts on developing resources and capabilities in other strategic orientations, being innovation a means towards reach these strategies.

\section{Hypotheses: Cooperation for innovation in the service sector}

Our model considers that companies that have greater resources and innovation skills will be more likely to cooperate. Thus, we assume that companies with a clear or proactive innovation orientation will develop capabilities and organizational routines to develop innovation processes; however, companies with a reactive innovation orientation will be less likely to develop to the same extent these skills and resources.

Regarding cooperation for innovation, the development of the cooperation process involves the negotiation of the agreement, the coordination of two or more partners, and the resolution of conflicts (Arranz et al., 2019b). Poppo and Zenger (2002) and Liu et al. (2009) stand out the capacity for relationships and the creation of an environment of trust between partners as a key element in the management of cooperation agreements. These capabilities aim to promote participatory decision-making and joint problem solving, improving the reciprocal expectations and mutual adaptability, establishing relational norms that facilitate reaching agreements, solving problems, and achieving performance objectives. In this context, as Evangelista and Sirilli (1998) pointed out, a characteristic of innovation in the service sector is the interaction with customers and suppliers. Thus, innovative processes in 
the service sector encourage companies to develop capacities for interaction and communication with other organizations. Arranz et al. (2019b) emphasize that in the process of establishing cooperation, it is necessary that firms possess some capacities in the negotiation of the agreement. In this sense, having previous experience in innovation projects in the service sector facilitates the negotiation stage, as well as the preparation, design, and planning of the cooperation contract (Lu and Beamish, 2001; Arranz et al., 2016). Therefore, it is expected that companies that have a proactive orientation towards innovation, have greater capacities for communication, interaction, and negotiation, which will facilitate the establishment of agreements and increase the probability of cooperating. Hence we propose:

H1a. In the service sector, companies with a proactive orientation to innovation have a high probability to develop their innovation activities based on the establishment of cooperation agreements.

However, companies with a reactive orientation to innovation will be less likely to develop cooperative agreements for innovation. Contrary to what we have postulated in the previous hypothesis, companies with a reactive orientation to innovation will not have developed capacities and resources that facilitate establishing cooperation agreements. Furthermore, the difficulties associated with the development of innovation, such as the uncertainty and risk of the project, must be added to the difficulties of developing cooperation agreements (Arranz et al.,2019b; Chowdhury et al., 2016). Hence, we propose:

$\boldsymbol{H 1 b}$. In the service sector, companies that develop their innovation activities according to a reactive orientation to innovation have a low probability of establishing cooperation agreements.

A firm in a proactive position in the development of innovation processes will find in the diversification of cooperation agreements a series of advantages. Thus, the consumer's cooperation agreements help define innovations, providing complementary skills or knowledge, and mitigating the risks and the difficulties associated with the development of innovations (Hagedoorn, 2006; Hoyer et al., 2010). Suppliers are also key sources of innovations (von Hippel, 1988), contributing to the definition of service specifications (Nordin and Kowalkowski, 2010; Selviaridis and Spring, 2010) and helping solve potential complications during the service delivery. These agreements increase their significance when the innovation being developed is more novel or complex (Fliess and Becker, 2006). 
According to Tether (2002) and Monjon and Waelbroeck (2003), cooperation with universities and research centres increase the probability of introducing new goods or services to the market. In general, managers perceive universities as a source of low-cost, low-risk, and specialized knowledge focussed on basic or more generic R\&D and long-term strategic research (Bayona-Sáez and García-Marco, 2010). In the case of agreements with competitors help, for example, to reduce the costs and risks associated with large projects (Branstetter and Sakakibara, 2002; Peng et al., 2012). Therefore, firms with a proactive orientation towards innovation will look for in each case the most suitable partner to the needs of the innovative development, increasing the probability of diversifying in the cooperation agreements. Moreover, in line with Hypothesis 1a, the resources and capacities generated in the innovation process, such as the ability for interaction, communication, and negotiation, will facilitate the establishment of cooperation agreements. Additionally, the development of innovation processes creates in companies a technological prospective capacity, which will facilitate the searching and finding the most suitable technologies and partners for their cooperation agreements. Hence, we propose:

H2a. In the service sector, companies that develop their innovation activities based on a proactive orientation to innovation have a high probability of cooperating with a diversity of partners.

However, the diverse range of partners entails additional resources and capabilities. Using the same reasoning as in the previous hypotheses, the establishment of cooperation agreements with a diversity of partners requires the possession of resources and capabilities for searching, negotiating and planning of cooperation agreements (Chesbrough, 2010); additionally, the establishment of communication channels with different partners and cultures is a problem to add to the very complexity of cooperation agreements (Hagedoorn et al., 2006). More specifically, cooperation with universities due to the different nature of these institutions traditionally has been a source of obstacles and difficulties; for example when defining objectives, setting goals and execution, or even because of communication problems (Hagedoorn et al., 2006). In this same line, cooperation with competitors is perceived by managers as high-risk cooperation (Arranz et al., 2019b). Additionally, the unbalanced cooperation between partners due for example to the different sizes or the asymmetry of interests has been also a source of difficulties in cooperation agreements 
(Hagedoorn et al., 2006). Therefore, a firm with a reactive orientation will be less inclined to diversify cooperation agreements, derived from their lack of resources and capacities, and to the difficulties of establishing and managing cooperation agreements with a variety of partners. Hence, we propose:

H2b. In the service sector, companies that develop their innovation activities according to a reactive orientation to innovation have a low probability of cooperating with a diversity of partners.

\section{Research Methodology}

\section{Unit of analysis and target study population}

The unit of analysis in this research is the firm, and the data are taken from the Technological Innovation Panel (PITEC). This survey has been conducted bi-annually by National Statistics Institute (INE) since 2001 and replicates for Spain the questionnaire used by The Community Innovation Survey (CIS), following the guidelines of the Oslo Manual and the Frascati Manual (Gault, 2013) using a standardized questionnaire. PITEC contains firm-level data and provides information about the company (employment, sales, geographic market, industry sector, etc.) as well as detailed information regarding its innovation activity (innovation expenditures, different kinds of innovation output, cooperation between firms, public financial support, barriers to innovation, and so on).

PITEC has a panel structure. The reference period for the research is 2011-2013. After a filtering process, our final sample is 2,622 firms of which have conducted some sort of innovation throughout the period studied. Table 1 shows the distribution of the sample according to the sectoral classification (NACE Revision 2). Table 2 shows all the variables used in this study.

\section{Statistical Analysis}

Our study analyses how companies in the services sector cooperate in the development of innovation. For this, we have performed various analyses.

To explore the behaviour of service companies in terms of cooperation and innovation, we proceeded to classify companies. In line with the previous works of Trigo and Vence (2012), Mina et al. (2014), Kim et al. (2015), and Helkkula et al. (2018), who pointed out that the service sector comprises a heterogeneity of innovation modes, and for a proper 
understanding of how the service sector innovates, we proceeded to classify the sample using hierarchical cluster statistical methodology, to determine groups of firms according to their strategic orientations to innovation (proactive/reactive). Unlike other cluster methods, the hierarchical cluster allows us to obtain all the possible and significant groupings of companies, which allows us to analyze various solutions and find the most suitable one.

As a classification variable, we use the strategic orientation of the firm. While companies with a proactive orientation towards innovation will focus on innovative competences and intensity and diversity of innovation, companies with a reactive orientation will focus on other strategic orientations, with innovation being a means to achieve, for example, strategies for developing new products, strengthening their market position or improving their competitiveness. We also use two classification measures in cluster analysis. A first measure is obtained by a factor analysis of the various types of innovation performed (product, process, organizational, marketing), obtaining a variable that measures the intensity and diversity of the innovations made in the firm (innovation orientation) ${ }^{2}$ (Cronbach Alpha, 0.792). Thus, the greater the diversity and intensity of innovations performed, the greater will be the resources and capabilities developed by the company, which corresponds with a proactive orientation to innovation. The second classification measure is obtained by a factor analysis of the other innovation objectives (product-oriented objectives; process-oriented objectives; environmental-oriented objectives; employee-oriented objectives), that measures the intensity and diversity of other strategic orientations that companies can achieve ${ }^{3}$ (Cronbach Alpha 0.835). These companies carry out innovations but as a means to reach other strategies (reactive orientation to innovation). With these two factors as classification variables, we performed a hierarchical cluster analysis. A hierarchical cluster allows flexibility in the construction of groups of companies, analyzing various solutions based on the distribution of companies in each cluster. Initially, we carried out a prior check of all possible combinations of companies based on these two measures. Thus, we initially discarded a number greater than five clusters, since the impact of the classification measures

\footnotetext{
${ }^{2}$ To check whether the innovation orientation measures diversity in addition to intensity, we have obtained a new variable as a sum of the various types of innovation carried out. With this new variable that measures the diversity of innovation, we check the correlation with the variable intensity of the innovation made, obtaining a value of 0.911 , being able to accept, therefore, the measure of diversity.

${ }^{3}$ In line with previous analysis, we have verified that the variable admits diversity in addition to intensity. The correlation coefficient obtained is 0.950 , allows us to affirm it.
} 
was not very significant. With this previous check, we considered four possible solutions: the first solution based on two clusters up to the fourth solution based on five clusters. Figure 1 and Table 2 show both the distribution of the number of companies in each cluster, as well as the behaviour of each cluster according to the classification variables.

To interpret the various solutions obtained, Figure 1 presents in the vertical axis the average value of the classification variables (innovation orientation; other strategic orientations), and in the horizontal axis, the clusters obtained in each solution. For example, if we analyse the solution of two clusters, the Cluster 1 is formed by 1,853 companies (see Table 3), and it is observed in Figure 1d that does not show a clear orientation, as reflected in that the average values of the classification variables are close to zero. However, Cluster 2, consisting of 407 companies (see Table 3), has a clear orientation towards innovation, as shown by the average values close to 2 (see Figure 1d).

If we analyse the solution of five clusters, Cluster 1 (formed by 800 companies) and Cluster 3 (579 companies) do not display a clear strategic orientation, as shows the value of the scale near to zero (Figure 1a). A second group is formed by 474 companies (Cluster 4 ) in which prevails other strategic orientation to innovation. Third and fourth groups are formed by 346 (Cluster 2) and 61 companies (Cluster 5) respectively, in which prevail the orientation to innovation, especially in Cluster 2.

In the case of the solution of four clusters, it is observed in Table 3 and Figure $1 \mathrm{~b}$ very similar results. Two clusters show an innovation orientation (Cluster 2 and 4) with 346 and 61 companies respectively; Cluster 3 (474 companies) shows other strategic orientation of innovation, and 1379 companies (Cluster 1) have not any orientation. We could repeat these explanations for the various solutions, but we can conclude that there is a group of companies that do not have a clear orientation to innovation, as shown in the average values of the classification variables close to zero. Another group formed by companies oriented towards innovation (proactive orientation), and the last group formed by companies with other strategic orientation to innovation (reactive orientation).

Once the clustering of the set of firms was carried out it was clear that the solution of three clusters was the most suitable for the analysis as a balance between the large concentrations offered by only two clusters and the excessive division in the case of five clusters that provided very little additional information. Therefore, we employ the solution of three 
clusters, containing 1379 (Cluster 1), 407 (Cluster 2), and 474 (Cluster 3) firms respectively. In this solution, it can be observed both tendencies: the firms that prioritize the innovation in their actions (Cluster 2) and the firms that are oriented to other innovation objectives (Cluster $3)$.

To analyse our research question (how companies cooperate in innovation in the services sector) we used the Ordinal Logit Regression Model as the econometric model. We included as dependent variables the types of innovation (product innovation, process innovation, organizational innovation, and marketing innovation). As independent variables, we used cooperation agreements based on partner typology (other firms in the group, suppliers, private customers, public customers, competitors, consultants, universities, and research centres), and a set of control variables.

\section{Robustness analysis}

We have tested the robustness of all models through the Variance Inflation Factor (VIF) and Durbin-Watson, obtaining in all models acceptable values. Also, we have tested the common method variance (CMV) and common method bias (CMB), following Podsakoff et al's (2003) method. This analysis reveals five distinct latent constructs that account for 57.28 percent of the variance. The first factor accounts for 20.02 percent of the variance, which is below the recommended limit of 50 percent. This result suggests CMV and CMB are not a concern in the results of our regressions.

\section{Results and Discussion}

Table 4 shows the modes of innovation performed by each group of firms. Cluster 1 contains firms that concentrate on developing organizational and marketing innovations (non-technological innovations). Clusters 2 and 3 both carry out technological as well as nontechnological innovations, having Cluster 2 the highest percentages of innovation in all areas.

Table 5 reports the percentage of firms by sub-sectors included within each cluster. It is observed that there is no correspondence between classification by sector and the firm orientation to innovation, as shows the existence in each cluster of several firms from each sub-sector. This result corroborates the literature reflecting the inadequacy of using sectorial classification to determine the innovation patterns in the service sector (Gallouj and Svona, 
2009; Chang et al., 2012; Trigo and Vence, 2012). Regarding Hypotheses 1a and 1b, which raise whether the strategic orientation to innovation affects the probability of innovating by developing cooperation agreements, we have carried out a cross-table analysis, using as variables, the cooperation agreements (more specifically, if companies make any type of cooperation agreement) and the cluster they belonging. Our results show that while firms in Cluster 1 do not carry out cooperation agreements to develop innovations, the opposite is true for the other two. The greatest concentration of this can be seen in Cluster 2 (proactive orientation to innovation), where 62.2 percent of firms have cooperation agreements, as opposed to Cluster 3 (reactive orientation to innovation) with only 36.3 percent. Therefore, the hypotheses are corroborated and show that companies with a proactive orientation towards innovation use cooperation agreements more frequently in this process (Authors). As we have argued, in the service sector interaction and communication in innovative development create capabilities that facilitate the use of cooperation agreements.

Regarding Hypotheses $2 \mathrm{a}$ and $2 \mathrm{~b}$, which raise whether the strategic orientation to innovation affects the probability of cooperating with a diversity of partners, we have proceeded to analyze each cluster separately. In the case of Cluster 1, we do not proceed to analyze it, since it does not show any strategic orientation. Table 6 shows the result for Cluster 2 (proactive orientation to innovation). It is observed that in the development of product innovation the cooperation between suppliers $(\beta=0.490, p<0.001)$ and customers $(\beta=0.329, p<0.005)$ is significant, as well as the collaboration with firms within the group. $(\beta=0.392, p<0.010)$. In addition, cooperation in process innovation is carried out mainly with suppliers $(\beta=0.381, \mathrm{p}<0.001)$ and firms within the group $(\beta=0.395, \mathrm{p}<0.005)$. In the case of non-technological innovation, collaboration with suppliers is significant $(B=0.446, p$ $<0.001 ; \beta=0.197, \mathrm{p}<0.010$ ), as is the case of organisational and marketing innovation. Moreover, our results also show that cooperation with universities for product innovation $(\beta=$ $0.273, \mathrm{p}<0.010)$ and for process innovation $(\beta=0.244, \mathrm{p}<0.010)$; and research centres in the case of product innovation $(\beta=0.231, \mathrm{p}<0.010)$ and in the case of process innovation $(\beta=0.239, p<0.010)$, is significant. It is also observed that companies with a proactive orientation to innovation cooperate with competitors $(\beta=0.343, p<0.005)$ in the case of organizational innovation. Similarly, our results show a positive impact of consultants in the development of marketing innovations $(\beta=0.274, p<0.010)$. In the analysis of cooperation 
agreements in Cluster 3, that groups firms with a reactive orientation to innovation (Table 7), it is observed a minor scope in the partner typology, which is centred exclusively in the cooperation with suppliers, for product innovation $(\beta=0.453, p<0.010)$ and process innovation $(\beta=0.234, p<0.010)$. In the case of non-technological innovations (organizational and marketing innovations), no cooperation agreements are established. Hence, we can conclude that Hypotheses $2 \mathrm{a}$ and $2 \mathrm{~b}$ are corroborated.

As a final remark, it can be summarized the different characteristics exhibit by clusters. Cluster 1 does not show a strategic orientation to innovation. This group of firms is centred exclusively on intangible innovations, without establishing cooperation agreements with other partners. The companies could be classified in the typology defined as supplierdominated firms (Tether and Tajar, 2008), lonely innovators (Trigo and Vence, 2012), or market-oriented (Hollestein, 2003). The group comprises companies offering personal services (e,g, restaurants and hotels, laundry, repair services, barber, and beauty services), public and social services (e.g., education, healthcare, and public administration), post and courier services. Trigo and Vence (2012) and Hollestein (2003) point out that they are firms characterized by weak expertise in $R \& D$, engineering capability, and in-house software, with little or no possibility of cooperation derived from minor involvement with other economics actors.

Cluster 2 shows a proactive orientation, where the behavioural decision that drives innovation development is the skill acquired as a result of the degree of strategic orientation of the innovation activities. It is noteworthy that here there is a high percentage of use of cooperation agreements. In these agreements vertical and supply chain cooperation have a significant impact on innovation results, showing similar behaviour to that of firms with high technological intensity in the manufacturing sector (den Hertog, 2000; Tether and Tajar, 2008;). This group of service firms could have parallels with Pina and Tether (2016) classification of knowledge-intensive business services (KIBS). Following these authors, KIBS firms are recognized as being among the most dynamic sectors of advanced economies, not only achieving high rates of innovation but also cooperating with their clients in the general innovation process (Leiponen, 2005; Freel, 2006).

Cluster 3 shows other strategic orientation in terms of innovative development. It reveals a low level of use of cooperation agreements, collaborating almost exclusively with suppliers, 
which leads us to conclude that these could be firms with little resources for cooperation and innovation. In general, we observe no coincidence with previous taxonomies in this group, since they comprise a wide spectrum of companies from all sectors.

\section{Conclusion}

This paper aimed to explore cooperation for innovation development in the service sector. Our study extends the current literature on the relationship between cooperation and innovation in the service sector (Tether and Tajar, 2008; Trigo and Vence, 2012; Evangelista, 2000; Chang et al., 2012).

Firstly, from Resources-Based View (RBV), Eisenhardt and Schoonhoven (1996) already pointed out that cooperation agreements were a way of obtaining for most companies critical resources, considering the possibility of accessing these resources through partnerships or cooperation. Moreover, it has been established that cooperation is a driver of innovation, providing resources for innovative development in the service sector (Chang et al., 2012; Trigo and Vence, 2012). Hagedoorn et al. (2006) indicated that the objectives of the cooperation for innovation include cost reduction, risk sharing, access to financial capital, complementary assets, improved capacity for rapid learning and knowledge transfer. In this sense, as to search for assets, firms may turn to different types of partners, such as consumers, suppliers, competitors, universities, among others (Hagedoorn et al., 2006; Schneider and Spieth, 2013; Badillo and Moreno, 2016; Hyll and Pippel, 2016; Arranz et al., 2019b). Thus, our findings suggest that cooperation and innovation in the services sector are influenced by the strategic orientation of the firm. Companies with a greater orientation towards innovation will further develop innovation resources, which will facilitate the establishment of cooperation agreements. This will mean an increase both in the frequency of use of cooperation agreements as well as in the diversity of partners. However, companies in the service sector with other strategic orientations of innovation and therefore without an emphasis on the development of these resources will be less inclined to building partnerships for innovation.

Secondly, we provide empirical evidence on the innovation modes in the service sector. As we have pointed out, the classification of the service sector starts from the assumption that firms have a certain amount of freedom to develop their innovation strategy. The 
literature on innovation in the service sector has recognized the existence of a plurality of innovation patterns, which has generated a wealth of studies that try to classify the sector to improve the understanding of the diversity of such innovation patterns. However, the previous works that have attempted to offer taxonomy in the service sector from different lines of research have been profuse but inconclusive. Thus, in line with the pioneering work of Soete and Miozzo (1989), which proposed creating a typology that has inspired many other studies in this field (for example, Gallouj and Weinstein, 1997; Evangelista, 2000; Miozzo and Soete, 2001; Sundbo and Gallouj, 2000; Hollenstein, 2003; Hipp and Grupp, 2005; De Jong and Marsili, 2006; Tether and Tajar, 2008; Vargo and Lusch, 2008; Trigo and Vence, 2012), our work extends previous literature, considering that innovation in the service sector is based on the strategic orientation of firms. Thus, we have proved that co-exist firms with a reactive orientation to innovation, with other firms that have a proactive positioning in innovative development. Moreover, derived from the greater strategic orientation to innovation and penetration of innovation modes, proactive firms of the service sector have greater intensity and diversity in the development of cooperation agreements.

Finally, the study has explored the cooperation for innovation in Spain. Because it is acknowledged that this reduces the generalizability of its results, future studies must address the specificities of other countries by widening the geographical scope of the analysis.

\section{References}

Aas, T. H., \& P. E. Pedersen (2010). The firm-level effects of service innovation: a literature review. International Journal of Innovation Management, 14(05), 759-794.

Arranz, N., M. F. Arroyabe, J. Li, \& J.C. Fernandez de Arroyabe (2019a). An integrated model of organisational innovation and firm performance: Generation, persistence and complementarity. Journal of Business Research, 105, 270-282.

Arranz, N., F. Arroyabe, M. and Fernandez de Arroyabe, J.C. (2019b). Obstacles of innovation and institutional support in the cooperation agreements: The Spanish case. European Journal of Innovation Management, 23(4), 696-712.

Arranz, N., MF. Arroyabe And JC. Fernandez De Arroyabe (2016). Alliance-building Process as Inhibiting Factor for SME International Alliances. British Journal of Management. 27 (3), 497-515. 
Badillo, E.R. and R. Moreno (2016). What drives the choice of the type of partner in R\&D cooperation? Evidence for Spanish manufactures and services. Applied Economics, 48(52), 5023-5044.

Ballantyne, D., \& R. J. Varey (2006). Creating value-in-use through marketing interaction: the exchange logic of relating, communicating and knowing. Marketing Theory, 6(3), 335348.

Ballot, G., F. Fakhfakh, F. Galia and A. Salter (2015). The fateful triangle: Complementarities in performance between product, process and organizational innovation in France and the UK. Research Policy, 44(1), pp.217-232.

Barney, J. (1991). Firm resources and sustained competitive advantage, Journal of Management, 17, 99-120.

Baruch, G. K., L. Biener and R. Barnett (1987). Women and gender in research on work and family stress. American Psychologist, 42(2), 130.

Bayona-Sáez, C. and T. García-Marco (2010). Assessing the effectiveness of the Eureka Program. Research Policy, 39(10), 1375-1386.

Branstetter, L. G. and M. Sakakibara (2002). When do research consortia work well and why? Evidence from Japanese panel data. American Economic Review, 92(1), 143-159.

Brickson, S. L. (2005). Organizational identity orientation: Forging a link between organizational identity and organizations' relations with stakeholders. Administrative science quarterly, 50(4), 576-609.

Camarero, C., and M. J. Garrido (2012). Fostering innovation in cultural contexts: Market orientation, service orientation, and innovations in museums. Journal of Service Research, 15(1), 39-58.

Castellacci, F. (2010). The internationalization of firms in the service industries: Channels, determinants and sectoral patterns, Technological Forecasting and Social Change, 77, $500-513$.

Chang, Y. C., J. D. Linton and M.N. Chen (2012). Service regime: An empirical analysis of innovation patterns in service firms, Technological Forecasting and Social Change, 79, 1569-1582.

Chesbrough, H.W. (2011). Bringing open innovation to services. MIT Sloan Management Review, 52(2), 84-91. 
Chowdhury, I.N., T. Gruber, and J. Zolkiewski (2016). Every cloud has a silver lining: Exploring the dark side of value co-creation in B2B service networks. Industrial Marketing Management, 55, 97-109.

Day, G. S. (1994). The capabilities of market-driven organizations. Journal of marketing, 58(4), 37-52.

De Jong, J.P. and O. Marsili (2006). The fruit flies of innovations: A taxonomy of innovative small firms. Research policy, 35(2), pp.213-229.

Den Hertog, P. (2010). Managing Service Innovation: Firm-level Dynamic Capabilities and Policy Options. Dialogic Innovatie and Interactie, Utrecht.

Eisenhardt, K. M. and J.A. Martin (2000). Dynamic capabilities: What are they?, Strategic Management Journal, 21, 1105-1121.

Eisenhardt, K. M. and C. Schoonhoven (1996). Resource-based view of strategic alliance formation: Strategic and social effects in entrepreneurial firms. Organization Science, 7(2), 136-150.

Evangelista, R. (2000). Sectoral patterns of technological change in services, Economics of Innovation and New Technology, 9, 183-221.

Evangelista, R. and M. Savona (2003). Innovation, employment and skills in services: Firm and sectoral evidence, Structural Change and Economic Dynamics, 14, 449-474.

Evangelista, R. and G. Sirilli (1998). Innovation in the service sector results from the Italian statistical survey. Technological Forecasting and social change, 58(3), 251-269.

Evangelista, R. and A. Vezzani (2010). The economic impact of technological and organizational innovations. A firm-level analysis. Research Policy, 39(10), pp.1253-1263.

Ferrell, O. C., T. Gonzalez-Padron, G. Hult and I. Maignan (2010). From market orientation to stakeholder orientation. Journal of Public Policy \& Marketing, 29(1), 93-96.

Fitzsimmons, J.A., M.J. Fitzsimmons and S. Bordoloi (2008). Service management: operations, strategy, information technology. New York, McGraw-Hill.

Fliess, S. and U. Becker (2006). Supplier integration: controlling of co-development processes, Industrial Marketing Management, 35, 28-44.

Freel, M. (2006). Patterns of technological innovation in knowledge-intensive business services. Industry and Innovation, 13(3), 335-358. 
Freel, M., (2016). Knowledge-intensive business services: geography and innovation. Routledge.

Frow, P., S. Nenonen, A. Payne and K. Storbacka (2015). 'Managing co-creation design: A strategic approach to innovation', British Journal of Management, 26, pp. 463-483.

$\mathrm{Fu}, \mathrm{W}, \mathrm{Q}$. Wang, and X. Zhao (2017). The influence of platform service innovation on value co-creation activities and the network effect. Journal of Service Management, 28(2), 348388.

Fuglsang, L., and R. Rønning (2015). On innovation patterns and value-tensions in public services. The Service Industries Journal, 35(9), 467-482.

Gatignon, H. and J. Xuereb (1997). Strategic orientation of the firm and new product performance. Journal of marketing research, 34(1), 77-90.

Gallouj, F. and M. Savona (2009). Innovation in services: A review of the debate and a research agenda, Journal of Evolutionary Economics, 19, 149-172.

Gallouj, F. and O. Weinstein (1997). Innovation in services, Research Policy, 26, 537-556.

Gallouj, F., L. Rubalcaba, and P. Windrum (2013). Public-Private Innovation Networks in Services. Edward Elgar Publishing.

Gault, F. (2013). The Oslo Manual. In Handbook of innovation indicators and measurement. Edward Elgar Publishing.

Gronroos, C. (1990). Relationship approach to marketing in service contexts: The marketing and organizational behavior interface. Journal of business research, 20(1), 3-11.

Guisado-González, M., C. Ferro-Soto and M. Guisado-Tato (2016). Assessing the influence of differentiation strategy and R\&D subsidies on R\&D cooperation. Technology Analysis \& Strategic Management, 28(7), 857-868.

Hagedoorn, J., N. Roijakkers and H. Kranenburg (2006). Inter-firm R\&D networks: The importance of strategic network capabilities for high-tech partnership formation, British Journal of Management, 17, 39-53.

Helkkula, A., C. Kowalkowski, and B. Tronvoll (2018). Archetypes of service innovation: implications for value cocreation. Journal of Service Research, 21(3), 284-301.

Hertog, P. D., F. Gallouj and J. Segers (2011). Measuring innovation in a 'low-tech'service industry: the case of the Dutch hospitality industry. The Service Industries Journal, 31(9), 1429-1449. 
Hidalgo, A. and L. D'Alvano (2014). Service innovation: Inward and outward related activities and cooperation mode. Journal of Business Research, 67(5), 698-703.

Hipp, C. and H. Grupp (2005). Innovation in the service sector: The demand for servicespecific innovation measurement concepts and typologies. Research policy, 34(4), pp.517-535.

Hollenstein, H. (2003). Innovation modes in the Swiss service sector: A cluster analysis based on firm-level data, Research Policy, 32, 845-863.

Hoyer, W. D., R. Chandy, M. Dorotic, M. Krafft and S. Singh (2010). Consumer cocreation in new product development. Journal of service research, 13(3), 283-296.

Hsieh, J.K. and Y.C. Hsieh (2015). Dialogic co-creation and service innovation performance in high-tech companies. Journal of Business Research, 68(11), 2266-2271.

Hunt, S. D. and R. Morgan (1995). The comparative advantage theory of competition. Journal of marketing, 59(2), 1-15.

Hurley, R. F. and G. Hult (1998). Innovation, market orientation, and organizational learning: an integration and empirical examination. Journal of marketing, 62(3), 42-54.

Hyll, W., \& G. Pippel (2016). Types of cooperation partners as determinants of innovation failures. Technology Analysis \& Strategic Management, 28(4), 462-476.

INE (2020). Statistical Information. Instituto Nacional de Estadistica. https://www.ine.es/en/ Jääskeläinen, MA, S Kortelainen and JJ Hinkkanen (2013). Conceptualizing the co-creation of competitive advantage in technology-intensive B2B markets: Agent-based modeling approach. International Journal of Innovation Management, 17(3), 1-17.

Jevnaker, B. H., B. Tellefsen and M. Lüders (2015). Front-end service innovation: learning from a design-assisted experimentation. European Journal of Innovation Management, $18(1), 19-43$.

Jiménez-Zarco, A. I., M. P. Martínez-Ruiz and A. Izquierdo-Yusta (2011). The impact of market orientation dimensions on client cooperation in the development of new service innovations. European Journal of Marketing 46(1/2), 43-67.

Kim, M., J. Song and J. Triche (2015). Toward an integrated framework for innovation in service: A resource-based view and dynamic capabilities approach. Information Systems Frontiers, 17(3), 533-546. 
Koschatzky, K. (1999). Innovation networks of industry and business-related servicesrelations between innovation intensity of firms and regional inter-firm cooperation. European Planning Studies, 7(6), 737-757.

Lawson, B., and D. Samson (2001). Developing innovation capability in organisations: a dynamic capabilities approach. International Journal of Innovation Management, 5(03), 377-400.

Leiponen, A. (2005). Organization of knowledge and innovation: the case of Finnish business services. Industry \& Innovation, 12(2), 185-203.

Li, X., D. Gagliardi and I. Miles (2019). Innovation in R\&D service firms: evidence from the UK. Technology Analysis \& Strategic Management, 31(6), 732-748.

Liu, Y., Luo, Y., \& Liu, T. (2009). Governing buyer-supplier relationships through transactional and relational mechanisms: Evidence from China. Journal of Operations Management, 27(4), 294-309.

Lu, J. W. and P. Beamish (2001). The internationalization and performance of SMEs. Strategic management journal, 22(6-7), 565-586.

Mallin, C., G. Michelon and D. Raggi (2013). Monitoring intensity and stakeholders' orientation: how does governance affect social and environmental disclosure?. Journal of business ethics, 114(1), 29-43.

McCole, P., E. Ramsey and P. Ibbotson (2008). Factors that impact technology innovation adoption among Irish professional service sector SMEs. International Journal of Innovation Management, 12(04), 1-26.

Miles, I. (1993). Services in the new industrial economy. Futures, 25(6), 653-672.

Mina, A., E. Bascavusoglu-Moreau and A. Hughes (2014). Open service innovation and the firm's search for external knowledge. Research Policy, 43(5), 853-866.

Miotti, L. and F. Sachwald (2003). Co-operative R\&D: why and with whom? An integrated framework of analysis, Research Policy, 32, 1481-1499.

Miozzo, M. and L. Soete (2001). Internationalization of services: a technological perspective. Technological Forecasting and Social Change, 67(2-3), pp.159-185. 
Monjon, S. and P. Waelbroeck (2003). Assessing spillovers from universities to firms: Evidence from French firm-level data, International Journal of Industrial Organization, $21,1255-1270$.

Nardelli, G. (2017). Innovation dialectics: An extended process perspective on innovation in services. The Service Industries Journal, 37(1), 31-56.

Narver, J. C., and S. Slater (1990). The effect of a market orientation on business profitability. Journal of marketing, 54(4), 20-35.

Nordin, F. and C. Kowalkowski (2010). Solutions offerings: A critical review and reconceptualisation, Journal of Service Management, 21, 441-459.

Olavarrieta, S. and R. Friedman, R. (2008). Market orientation, knowledge-related resources and firm performance. Journal of Business Research, 61, 623-630

Oliveira, P. and E. von Hippel (2011). User as service innovators: The case of banking services, Research Policy, 40, 806-818.

Osborne, S.P. and K. Strokosch, (2013). It takes Two to Tango? Understanding the C oproduction of Public Services by Integrating the Services Management and Public Administration Perspectives. British Journal of Management, 24, pp.S31-S47.

Pavitt, K. (1984). Sectoral patterns of technical change: Towards a taxonomy and a theory, Research Policy, 13, pp. 343-373

Payne, A. F., K. Storbacka and P. Frow (2008). Managing the co-creation of value. Journal of the Academy of Marketing Science, 36(1), 83-96.

Peneder, M. (2010). Technological regimes and the variety of innovation behaviour: Creating integrated taxonomies of firms and sectors. Research Policy, 39(3), 323-334.

Peng, T. J. A., S. Pike, J. C. H. Yang and G. Roos (2012). Is cooperation with competitors a good idea? An example in practice, British Journal of Management, 23, 532-560.

Peteraf, M. A. (1993). The cornerstones of competitive advantage: a resource-based view. Strategic management journal, 14(3), 179-191.

Pina, K. and B. S. Tether (2016). Towards understanding variety in knowledge intensive business services by distinguishing their knowledge bases, Research Policy, 45, 401-413. PITEC (2014). Panel de Innovacion Tecnologica. Fundacion Espanola para la Ciencia y Tecnologia. Retrieved from https://icono.fecyt.es/PITEC/Paginas/descarga_bbdd.aspx 
Poppo, L. and T. Zenger (2002). Do formal contracts and relational governance function as substitutes or complements?. Strategic management journal, 23(8), 707-725.

Pyka, A., B. Schön, , P. Windrum, , L. Fuglsangand K. Frenken (2009). Cooperation for innovation in services: an economic approach to the theory of innovation networks in the service industries. ServPPIN. Hohenheim.

Rodríguez, A. and M.J. Nieto (2010). Cooperation and innovation in the internationalization of knowledge-intensive business services. Reshaping the boundaries of the firm in an era of global interdependence. Progress in International Business Research, 5, 247-270

Sasser, W.E., Olsen, R.P., \& Wyckoff, D.D. (1978). Management of Service Operations. Allyn and Bacon, Boston.

Sastre, J.F. (2015). The effect of national and international R\&D cooperation: differences between manufactures and services. International Journal of Services Technology and Management, 21(1-3), 146-162.

Schneider, S., and P. Spieth (2013). Business model innovation: Towards an integrated future research agenda. International Journal of Innovation Management, 17(01), 1-34.

Selviaridis, K. and M. Spring (2010). The dynamics of business service exchanges: Insights from logistics outsourcing. Journal of Purchasing and Supply Management, 16(3), 171184.

Soete, Luc LG, and Marcela Miozzo. (1989). Trade and development in services: a technological perspective. Merit,.

Spohrer, J. and P.P. Maglio (2008). The emergence of service science: Toward systematic service innovations to accelerate co-creation of value. Production and Operations Management, 17(3), 238-246.

Sundbo, J. and F. Gallouj (2000). Innovation as a loosely coupled system in services. In: J. S. Metcalfe and I. Miles (eds.), Innovation Systems in the Service Economy, Measurements and Case Study Analysis, 43-68. Kluwer, Boston.

Tether, B. (2002). Who co-operates for innovation, and why: An empirical analysis, Research Policy, 31, 947-967.

Tether, B. (2005). Do services innovate (differently)? Insights from the European innobarometer survey. Industry \& Innovation, 12(2), 153-184. 
Tether, B. and A. Tajar (2008). The organisational-cooperation mode of innovation and its prominence amongst European service firms, Research Policy, 37, 720-739.

Tether, B.S. (2005). Do services innovate (differently)? Insights from the European innobarometer survey. Industry \& Innovation, 12(2),.153-184.

Torugsa, N. A., A. Arundel and P. L. Robertson (2018). Applying configurational thinking to identify recipes for producing service innovations in the service sector. International Journal of Innovation Management, 22(06), 1-23.

Trigo, A. and X. Vence (2012). Scope and patterns of innovation cooperation in Spanish service enterprises, Research Policy, 41, 602-613.

Van Beers, C. and F. Zand (2014). R\&D cooperation, partner diversity, and innovation performance: an empirical analysis. Journal of Product Innovation Management, 31(2), 292-312.

Vargo, S.L. and R. Lusch (2008). Service-dominant logic: continuing the evolution. Journal of the Academy of marketing Science, 36(1), 1-10.

von Hippel, E. (1988). The Sources of Innovation, Oxford University Press, New York.

Yang, C. W. (2016). Orchestrating knowledge-creating networks: lessons from Taiwan's health services sector. Technology Analysis \& Strategic Management, 28(6), 703-716.

Zhou, K. Z., C. K.Yim and , D. K. Tse (2005). The effects of strategic orientations on technology-and market-based breakthrough innovations. Journal of Marketing, 69(2), 4260. 
Table 1. The distribution of the sample according to the sectoral classification (NACE Revision 2)

\begin{tabular}{llcc}
\hline Sector & \multicolumn{1}{c}{ NACE } & N & \% \\
\hline COMMERCE AND RETAIL TRADE & $45,46,47$ & 582 & 22.0 \\
TRANSPORTATION AND STORAGE & $49,50,51,52,53$ & 97 & 3.7 \\
ACCOMMODATION AND FOOD SERVICE ACTIVITIES & 55,56 & 74 & 2.6 \\
TELECOMMUNICATIONS & 61 & 21 & 0.8 \\
SOFTWARE AND INFORMATION CONSULTING & 62 & 401 & 15.2 \\
OTHERS IC ACTIVITIES & $58,59,60,63$ & 123 & 4.7 \\
FINANCIAL AND INSURANCE ACTIVITIES & $64,65,66$ & 119 & 4.5 \\
REAL ESTATE & 68 & 43 & 1.6 \\
R\&D ACTIVITIES & 72 & 179 & 6.8 \\
OTHER ACTIVITIES & $69,70,71,73,74,75$ & 534 & 20.2 \\
ADMINISTRATIVE AND SUPPORT SERVICE & $77,78,79,80,81,82$ & 248 & 9.3 \\
ACTIVITIES & & & \\
EDUCATION & $85(\mathrm{excl.854)}$ & 13 & 0.3 \\
HUMAN HEALTH AND SOCIAL WORK ACTIVITIES & $86,87,88$ & 108 & 4.1 \\
ARTS, ENTERTAINMENT AND RECREATION & $90,91,92,93$ & 33 & 1.1 \\
OTHER SERVICE ACTIVITIES & 95,96 & 87 & 3.2 \\
\hline Total & & 2,622 & 100.0 \\
\hline
\end{tabular}

Table 2. Variables and Measures: Definition and Scales.

\begin{tabular}{|c|c|c|}
\hline Variables & Definition & Scale \\
\hline INNOVAPRODUCT & 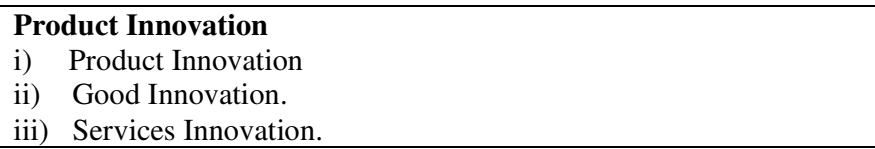 & 1,0 \\
\hline INNOVAPROCESS & $\begin{array}{l}\text { Process Innovation } \\
\text { i) Innovation manufacturing methods. } \\
\text { ii) Logistics systems innovation. } \\
\text { iii) Support innovation for the processes. }\end{array}$ & 1,0 \\
\hline INNOVAORGANISATION & $\begin{array}{l}\text { Organizational Innovation } \\
\text { i) Innovation in new or improved management systems. } \\
\text { ii) Innovation in the organization of work. } \\
\text { iii) Innovation in relations with companies or institutions. }\end{array}$ & 1,0 \\
\hline INNOVAMARKETING & $\begin{array}{l}\text { Marketing Innovation } \\
\text { i) Innovation in design or packaging. } \\
\text { ii) Innovation in new media or techniques for product promotion. } \\
\text { iii) Innovation in new methods for sales channels. } \\
\text { iv) Innovation in new methods of pricing goods or services. }\end{array}$ & 1,0 \\
\hline PRODUCTOBJECTIVE & $\begin{array}{l}\text { Importance of innovation objectives } \\
\text { i) Expansion of the range of goods or services; } \\
\text { ii) Substitution of outdated products or processes; } \\
\text { iii) Penetration into new markets; } \\
\text { iv) Higher market share; } \\
\text { v) Higher quality of goods or services. }\end{array}$ & $1,2,3,4$ \\
\hline PROCESSOBJECTIVE & $\begin{array}{l}\text { Importance of innovation objectives } \\
\text { i) Greater flexibility in production or service delivery. } \\
\text { ii) Increased production or service capacity } \\
\text { iii) Lower labour costs per unit produced. } \\
\text { iv) Less material per unit produced. } \\
\text { v) Less energy per unit produced. }\end{array}$ & $1,2,3,4$ \\
\hline ENVIRONMENTOBJECTIVE & $\begin{array}{l}\text { Importance of innovation objectives } \\
\text { i) Lower environmental impact. } \\
\text { ii) Improvement of the health and safety of its employees. } \\
\text { iii) Compliance with environmental, health, and safety requirements. }\end{array}$ & $1,2,3,4$ \\
\hline
\end{tabular}




\begin{tabular}{|c|c|c|}
\hline EMPLOYEEOBJECTIVE & $\begin{array}{l}\text { Importance of innovation objectives } \\
\text { i) Increase in total employment. } \\
\text { ii) The increase in skilled employment. } \\
\text { iii) Maintenance of employment }\end{array}$ & $1,2,3,4$ \\
\hline COOPERATION_i & $\begin{array}{l}\text { Cooperation: typology de socio i }(\mathbf{i}=\mathbf{1}, \ldots, \mathbf{8}) \\
\text { i) Group; } \\
\text { ii) Suppliers, } \\
\text { iii) Private customers, } \\
\text { iv) Public customers, } \\
\text { v) Competitors; } \\
\text { vi) Consultants, } \\
\text { vii) Universities, } \\
\text { viii) Research Centres }\end{array}$ & 1,0 \\
\hline \multicolumn{3}{|l|}{ Control Variables } \\
\hline SIZE & Number of employees in $\mathrm{t}$ & \\
\hline GROUP & Membership of a group of companies & 1,0 \\
\hline MARKET & $\begin{array}{l}\text { Company Market } \\
\text { i) Local / regional. } \\
\text { ii) National. } \\
\text { iii) } \\
\text { ive. } \\
\text { iv) }\end{array}$ & 1,0 \\
\hline
\end{tabular}

Table 3. The number and size of the clusters

\begin{tabular}{ccccc}
\hline & \multicolumn{4}{c}{ CLUSTER } \\
\hline $\mathbf{1}$ & 800 & $\mathbf{4}$ & $\mathbf{3}$ & $\mathbf{2}$ \\
$\mathbf{2}$ & 346 & 346 & 1379 & 1853 \\
$\mathbf{3}$ & 579 & 474 & 407 & 407 \\
$\mathbf{4}$ & 474 & 61 & 474 & \\
$\mathbf{5}$ & 61 & & & \\
Total & 2260 & 2260 & 2260 & 2260 \\
\hline
\end{tabular}
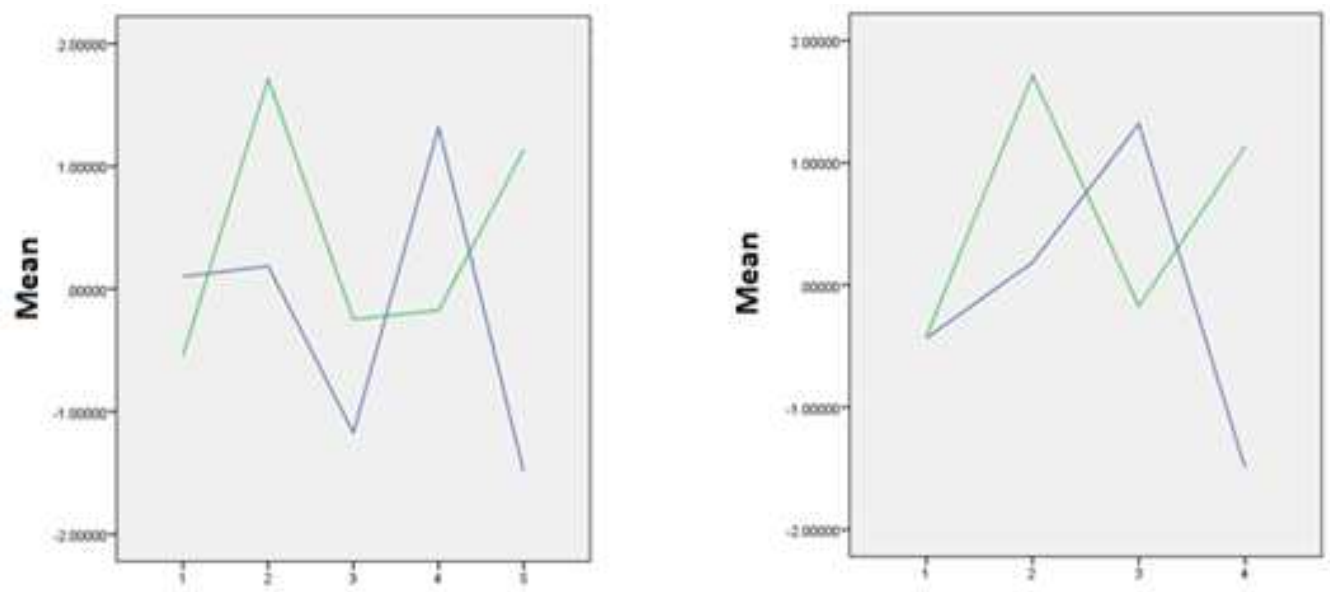
Clusters

Figure 1a. Solution for five clusters

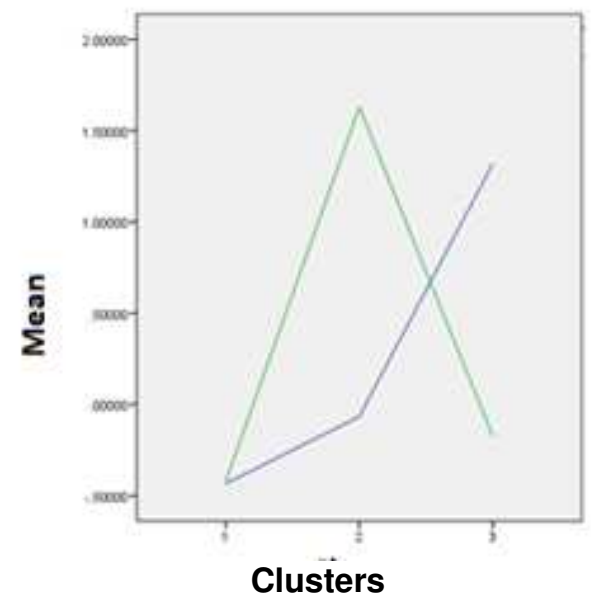

Figure 1c. Solution for three clusters
Clusters

Figure 1b. Solution for four clusters

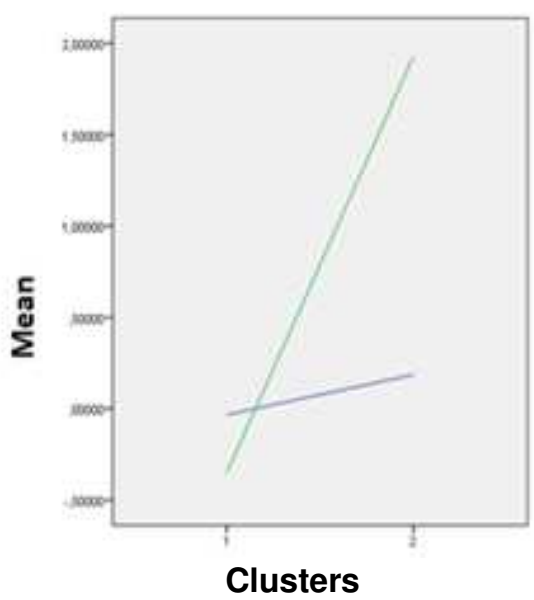

Figure 1d. Solution for two clusters

Innovation Orientation Factor

Other Strategic Orientations Factor

Figure 1. The impact of the two factors within the set of cluster's solutions.

Table 4. The innovation typology of each cluster

\begin{tabular}{llll}
\hline & Cluster 1 & Cluster 2 & Cluster 3 \\
& $\mathbf{\%}$ & $\mathbf{\%}$ & $\mathbf{\%}$ \\
\hline INNOVAPRODUCT (GOOD) & 0 & 53.2 & 22.4 \\
INNOVAPRODUCT (SERVICE) & 0 & 66.6 & 26.2 \\
INNOVAPROCESS (MANUFACTURING) & 0 & 51.4 & 16.6 \\
INNOVAPROCESS (LOGISTICS) & 0 & 27.5 & 5.6 \\
INNOVAPROCESS (SUPPORT) & 0 & 66.6 & 31.5 \\
INNOVAORGANISATION (ORGANISATION) & 23.6 & 86.4 & 23.4 \\
INNOVAORGANISATION (WORKPLACE) & 28.9 & 83.7 & 23.5 \\
INNOVAORGANISATION (EXTERNAL) & 11.2 & 58.1 & 8.1 \\
INNOVAMARKETING (DESIGN) & 10.3 & 40.5 & 5.1 \\
INNOVAMARKETING (PROMOTION) & 19.0 & 61.6 & 9.4 \\
INNOVAMARKETING (CHANNELS) & 14.1 & 54.4 & 6.9 \\
INNOVAMARKETING (PRICING) & 17.6 & 40.7 & 3.4 \\
\hline
\end{tabular}


Table 5 The distribution of service sub-sectors firms in each cluster

\begin{tabular}{lllllll}
\hline \multicolumn{1}{c}{ Sector } & \multicolumn{2}{c}{ Cluster $\mathbf{1}$} & \multicolumn{2}{c}{ Cluster 2 } & \multicolumn{2}{c}{ Cluster3 } \\
& $\mathbf{N}$ & $\mathbf{\%}$ & $\mathbf{N}$ & $\mathbf{\%}$ & $\mathbf{N}$ & $\mathbf{\%}$ \\
\hline COMMERCE AND RETAIL TRADE & 230 & $65.5 \%$ & 49 & $14.0 \%$ & 72 & $20.5 \%$ \\
TRANSPORTATION AND STORAGE & 61 & $57.0 \%$ & 24 & $22.4 \%$ & 22 & $20.6 \%$ \\
ACCOMMODATION AND FOOD SERVICE ACTIVITIES & 25 & $71.4 \%$ & 5 & $14.3 \%$ & 5 & $14.3 \%$ \\
TELECOMMUNICATIONS & 16 & $40.0 \%$ & 17 & $42.5 \%$ & 7 & $17.5 \%$ \\
SOFTWARE AND INFORMATION CONSULTING & 258 & $60.6 \%$ & 84 & $19.7 \%$ & 84 & $19.7 \%$ \\
OTHERS IT ACTIVITIES & 76 & $67.3 \%$ & 24 & $21.2 \%$ & 13 & $11.5 \%$ \\
FINANCIAL AND INSURANCE ACTIVITIES & 61 & $51.7 \%$ & 42 & $35.6 \%$ & 15 & $12.7 \%$ \\
REAL ESTATE & 11 & $68.8 \%$ & 1 & $6.3 \%$ & 4 & $25.0 \%$ \\
R\&D ACTIVITIES & 101 & $45.9 \%$ & 45 & $20.5 \%$ & 74 & $33.6 \%$ \\
OTHER ACTIVITIES & 296 & $61.4 \%$ & 78 & $16.2 \%$ & 108 & $22.4 \%$ \\
EDUCATION & 23 & $76.7 \%$ & 5 & $16.7 \%$ & 2 & $6.7 \%$ \\
HUMAN HEALTH AND SOCIAL WORK ACTIVITIES & 87 & $71.9 \%$ & 15 & $12.4 \%$ & 19 & $15.7 \%$ \\
ARTS, ENTERTAINMENT, AND RECREATION & 13 & $65.0 \%$ & 3 & $15.0 \%$ & 4 & $20.0 \%$ \\
OTHER SERVICE ACTIVITIES & 39 & $61.9 \%$ & 4 & $6.3 \%$ & 20 & $31.7 \%$ \\
Total & 1379 & $61.0 \%$ & 407 & $18.0 \%$ & 474 & $21.0 \%$ \\
\hline
\end{tabular}


Table 6. The impact of cooperation agreements for innovation in the firms on Cluster 2

\begin{tabular}{|c|c|c|c|c|}
\hline & $\begin{array}{l}\text { Product } \\
\text { Innovation } \\
\text { Estimated }\end{array}$ & $\begin{array}{l}\text { Process } \\
\text { Innovation } \\
\text { Estimated }\end{array}$ & $\begin{array}{l}\text { Organisational } \\
\text { Innovation } \\
\text { Estimated }\end{array}$ & $\begin{array}{c}\text { Marketing } \\
\text { Innovation } \\
\text { Estimated }\end{array}$ \\
\hline Size & $-3.240 \mathrm{E}-005$ & 6.613E-005* & $1.927 \mathrm{E}-006$ & $-2.015 \mathrm{E}-005$ \\
\hline Group & -.117 & $.605 * * *$ & $.301 *$ & $.299 *$ \\
\hline \multicolumn{5}{|l|}{ Market: } \\
\hline - Local & -.265 & .175 & .402 & -.124 \\
\hline - National. & .258 & -.104 & .228 & -.118 \\
\hline - UE. & $.308^{*}$ & -.218 & -.128 & -.203 \\
\hline - Others countries & .017 & -.268 & .098 & -.226 \\
\hline Coop_group &, $392 * *$ &, $395 * *$ & ,200 &, $180^{*}$ \\
\hline Coop_supplier &, $490 * * *$ &, $381 * * *$ &, $446 * * *$ &, $197 *$ \\
\hline Coop_clientsprivate &, $329 *$ & ,061 &, 025 &, 188 \\
\hline Coop_clientspublic & 084 & , 148 &, 114 & 037 \\
\hline Coop_competitors &, 117 &, 025 &, $343 * *$ &, 075 \\
\hline Coop_consultant & 044 & 237 & ,206 &, $274 *$ \\
\hline Coop_university &, $273 *$ & $.244 *$ & ,036 &,- 014 \\
\hline Coop_researchcentre &, $231 *$ &, $239 *$ & 090 &,- 010 \\
\hline-2 Log Likelihood & 2015.563 & 1926.751 & 2524.119 & 1901.340 \\
\hline Chi-Square & 82.952 & 76.890 & 31.896 & 60.237 \\
\hline$d f$ & 14 & 14 & 14 & 14 \\
\hline Sig. & .000 & .000 & .004 & .000 \\
\hline Cox and Snell & .058 & .054 & .023 & .039 \\
\hline Nagelkerke & .071 & .067 & .026 & .047 \\
\hline McFadden & .035 & .034 & .011 & .028 \\
\hline
\end{tabular}


Table 7. The impact of cooperation agreements for innovation in the firms on Cluster 3

\begin{tabular}{|c|c|c|c|c|}
\hline & $\begin{array}{l}\text { Product } \\
\text { Innovation } \\
\text { Estimated }\end{array}$ & $\begin{array}{l}\text { Process } \\
\text { Innovation } \\
\text { Estimated }\end{array}$ & $\begin{array}{l}\text { Organisational } \\
\text { Innovation } \\
\text { Estimated }\end{array}$ & $\begin{array}{c}\text { Marketing } \\
\text { Innovation } \\
\text { Estimated }\end{array}$ \\
\hline Size & $3.717 \mathrm{E}-005$ & $.000 * * *$ & $-2.009 \mathrm{E}-005$ & $1.289 \mathrm{E}-005$ \\
\hline Group & -.162 & .082 & $.563 * *$ & $.301 * *$ \\
\hline \multicolumn{5}{|l|}{ Market: } \\
\hline - Local & .633 & .509 & .520 & -.143 \\
\hline - National. & $1.205^{* *}$ & .082 & .282 & -.110 \\
\hline • UE. & $.455^{*}$ & -.197 & .348 & -.241 \\
\hline - Others countries & .146 & -.003 & -.231 &.- .039 \\
\hline Coop_group & ,257 & ,267 & ,456 &,- 091 \\
\hline Coop_supplier &, $453^{*}$ & ,234* & ,444 &,- 028 \\
\hline Coop_clientsprivate &,- 141 &,- 072 & ,087 & ,281 \\
\hline Coop_clientspublic &, 197 &, 319 &,- 425 &, 151 \\
\hline Coop_competitors &,- 190 &,- 088 &,- 074 &,- 083 \\
\hline Coop_consultant &, 127 & ,428 &, 055 & ,298 \\
\hline Coop_university &, $397(\mathrm{I})$ &,- 089 & ,422 &,- 361 \\
\hline Coop_researchcentre &, 104 &,- 211 & 032 &,- 274 \\
\hline-2 Log Likelihood & 884.842 & 945.409 & 1210.284 & 926.008 \\
\hline Chi-Square & 71.816 & 25.208 & 32.811 & 27.904 \\
\hline$d f$ & 14 & 14 & 14 & 14 \\
\hline Sig. & .000 & .033 & .003 & .000 \\
\hline Cox and Snell & .141 & .052 & .067 & .092 \\
\hline Nagelkerke & .161 & .059 & .072 & .102 \\
\hline McFadden & .073 & .025 & .026 & .076 \\
\hline
\end{tabular}

